\title{
12 Main varieties of Russian nationalism in the post-Soviet period and their relationship to European heritage and contemporariness
}

\author{
Joachim Diec
}

\section{Introduction}

The main task of this chapter is to draw a conceptual outline of the major trends in Russian nationalism after the collapse of the USSR in the context of its attitude to the European, or more broadly, Western question. To create such a typology, it is necessary to establish an insight into the diversity of those Russian nationalistic doctrines which functioned in that period with their main ideological positions by estimating the extent to which they are ingrained in the Russian tradition and investigating the type of impact on Russia's political and social life they can make in the next decades. This can be helpful in prognostic efforts which refer to the possible scenarios of the ideological development of contemporary Russian society, both in the internal and international perspective.

\section{Theoretical and methodological remarks}

As the main goal of our efforts is to review and structure the broad phenomenon of contemporary Russian nationalism, the theoretical basis of this study does not seem obvious. We observe the presence of different approaches in both Russian nationalist thought and political activities. Thus, the approach to this issue must necessarily be based on the inductive generalisation of the positions learned, regardless of the pre-existence of some primary assumptions and the hypotheses that existed in the researcher's tool kit.

However, there are certain key factors that facilitate some approaches to the detriment of others. There is, for example, a certain indisputable factor which is even reflected in the Russian language: the distinction between Russians as citizens (россияне) versus ethnic Russians (русские). Contemporary Russia is neither an entirely universal state (this was not even the case with the Soviet Union, despite its aspirations to being a defender of nations) nor a strictly national state dominated by one ethnic or cultural paradigm which was created for its support. What can be assumed at the outset of this study is the stronger position of primordialism in those cases where ethnicity has become the essence of nationalist doctrine. Alternatively, the state-oriented

DOI: $10.4324 / 9781003226123-15$ 
nationalistic circles would naturally precipitate instrumentalist interpretations of the Russian nation and its destiny in the international perspective.

Another theoretical hypothesis centres around the assumption that modernist approaches may not be as productive as they were in the context of many Western nations. We have to remember that Russian nationalists experienced the trauma of an imposed form of Marxism, which perceived any kind of nationalism as a useful element in the ideological superstructure of the capitalist society. That is why a post-Marxist and post-internationalist environment is naturally inclined to reject the idea of nationalism as an artificially constructed idea, one whose only function is to exploit the working class. In other words, the present study, being rooted in the inductive procedure, is directed toward a classification of approaches rather than toward the imposition of any single method.

\section{Recent analyses}

There are many important studies on Russian nationalism that have appeared in research efforts concerning Russian political thought. Some touch upon the issues of its earlier forms, the imperial period in particular. The more 'classical' forms, such as Slavophilism or Pan-Slavism, have been described in Walicki's monograph, ${ }^{1}$ whereas the phenomena of the period of decline and later forms of the trend were characterised by Laqueur. ${ }^{2}$ The very interesting problem of Russian nationalism in the USSR was discussed by Barghoorn in $1956^{3}$ and by Yitzak Brudny in $2000 .^{4}$

As far as the newest stages of the phenomenon in question are concerned, there are some valuable publications with such books as John B. Dunlop's Faces of Contemporary Russian Nationalism, ${ }^{5}$ the quite useful collection The New Russian Nationalism: Imperialism, Ethnicity and Authoritarianism 2000-15, edited by Pal Kolstø and Helge Blakkisrud, ${ }^{6}$ and Marlène Laruelle's brilliant monograph: Russian Nationalism: Imaginaries, Doctrines, and Political Battlefields of $2018^{7}$ (Laruelle offers a longer list of publications concerning Russian nationalism, and remains perhaps the most prolific expert in this area).

\section{The burden of tradition: a classification according to old standards?}

Russian nationalism has a long tradition, so there is a temptation to use either the divisions of its older forms or the general classifications of nationalism which are rooted in the basic models of understanding the concept of nation. In contemporary studies, Russian nationalism is traditionally classified into two categories: the ethnic and the statist. While promoting this kind of approach, Pål Kolstø refers to the two-axis scheme suggested by Sven Gunnar Simonsen, where one of the axes allows the drawing of a continuum from a pure orientation on the empire to an orientation on the 'core', and the other leads from a primarily statist orientation toward a purely ethnic one. The 
statists' positions stretch from Russian or Soviet imperialism to solidarity with the Russian Federation, whereas primarily ethnic nationalists represent either the supremacist position or, in the opposite extreme case, ethnic 'core' nationalism. ${ }^{8}$

This well-known model for portraying the complexity of Russian nationalism is useful and has been applied in several studies. However, what kind of device should be applied if the nationalist claims that the 'core' is imperial as such? If we return to the old Russian ideas conceived by such thinkers as Fyodor Dostoevsky or Fyodor Tyutchev, where the Russian soul is entirely universal and embraces the whole world and where Russia's destiny is to create the ultimate empire according to the principle of translatio imperii, we realise that no real ethnic or national core is designated apart from the providential idea of universalism and expansion under a religious banner. That is why a new look at understanding the trends in Russian nationalism would probably be more advisable than the traditional structure of axes previously mentioned.

The original assumption of this study is that nationalism (in the same way as the other political doctrines) never appears without a purpose. It is hard to find cases in the world's history of nationalism where nationalistic ideas were not a reaction to a real or imaginary threat which was posed by strangers or by an internally destructive factor. Russia has never been an exception, neither in the classical and Soviet past nor in the period of the Russian Federation. Russian nationalism is a phenomenon with a long tradition. During the reign of Nicholas I, 'Slavophilism' appeared as a reaction to the intellectual efforts of the Westerners, who preached Russia's inferiority in comparison with European cultural and political traditions. In the second half of the 19th century, during the time of great reforms, Pan-Slavism was supposed to be a response to Turkish and Western European dominance in the Black Sea region and the Balkans. Organisations that were usually classified as the Black Hundred formations fought against constitutionalists, liberal movements and socialist organisations; they were furious about the Jewish presence in the Russian economy and the press, as well as about the ambitions of Polish activists to regain independence. A study of nationalistic doctrines and movements cannot ignore the starting points of the processes, nor the irritating (or even threatening) phenomena which were woven into the overall situation underlying the emergence of various forms of nationalism. An influx of immigrants gives rise to an orientation in political thought which is different from the loss of independence, just as foreign religious or political hegemony does not cause the same phenomena as the confrontation of attractive ideologies which are foreign to the native culture.

After the collapse of the USSR, the political, economic, and social situation of the Russian people made them confront new challenges. Some old dilemmas remained, but there are many new factors that had to be taken into account while defining the perceived interests of contemporary Russia and the destiny of the Russian nation. The global geopolitical situation underwent 
a drastic transformation after 1990 and the changes predominantly impacted Moscow, which was reduced to the position of a regional power with rusting nuclear weapons in its pockets. Russia then experienced an economic disaster in the 1990s, was humiliated in the First Chechen War, and, after gaining a more convincing form of political and economic stability at the beginning of the third millennium, was forced to determine a relevant attitude to its North Caucasian Muslim citizens and immigration from Central Asia - a lost part of the vanished empire.

For these reasons, it may be inadequate to simply apply the well-rooted schemes and oppositions of Slavophil vs Westerner, monarchist vs republican, ethnic vs statist, etc. in the specific situation of the first three decades which followed the collapse of the Berlin Wall. A review of the recent trends in Russian nationalism ought to reflect the changing reality of the society in question, as with all historical nationalist phenomena in any country.

\section{The beginnings: a step towards freedom from communism and internationalist pressure}

A superficial glance at the oldest genuinely nationalistic organisation of the post-communist times, the National-Patriotic Front 'Pamyat' (Национальнопатриотический фронт «Память», НПФ «Память»), might surprise the observer since its roots can be traced back to the late 1970s when a traditionalistic and patriotic circle called Vityaz was created under the auspices of the Soviet Society for the Protection of Historical and Cultural Monuments (Общество охраны памятников истории и культуры). ${ }^{9}$ The most prominent Vityaz activists tried to defend Russian culture against the destructive trends of communist modernity. The most famous of them, Ilya Glazunov, created the patriotic club Rodina (Homeland) in the early 1960s. Later, in the 1970s, he successfully opposed the Master Plan for the reconstruction of Moscow, which threatened the historical part of the city with almost complete destruction. ${ }^{10}$ Positions like this were rare because of the pressure the regime exerted on intellectual circles. However, they always made their presence felt (at least after the Stalinist period) and were represented predominantly in art and literature with such famous names as Vladimir Soloukhin, a prominent traditionalist among Russian writers, who preached the necessity to preserve the treasury of Russian culture despite modernist pressure and wept over the lost architectural monuments of Moscow.

In 1980, the club became an organisation and was given wings by Gorbachev's perestroika. From 1988 until his death in 2003, the organisation's leader was Dmitry Vasilyev, a little-known actor but a talented organiser and ideologist who supported Gorbachev's reforms against communist radicals in the same way that he offered his support for Yeltsin. The reason was clear: the further society shifted from communism and the closer it came to traditional, non-Soviet Russia, the better for the Russian people. Soon, many organisations, which included 'Pamyat' in their names, appeared in several 
places throughout Russia, their leaders quarrelling with each other about ideological matters.

The general orientation of these groups was ostentatiously patriotic and linked to various versions of the Judeo-Masonic conspiracy theory. The slogan of Vasilyev's group (the 'true' National-Patriotic Front 'Pamyat') was 'God, Tsar, Nation', which generally reflected its preoccupation with reconstructing old Russia as defined by its religion, monarchy and national spirit. Vasilyev openly declares: 'I am a fascist, a Russian fascist, there is nothing wrong with that. If you want, I'm a monarchist, the union of the nation in the name of the monarchy is wonderful. But not a Nazi, not a National Socialist, this is the sphere of communist ideology.'11

This kind of Russian nationalism was a child of its time. Pamyat (which in Russian means memory) grew out of the experience of totalitarian communism, which annihilated everything associated with traditional Russia. It destroyed the former political system, which had existed for centuries, and had religious legitimacy. It also brutally persecuted Orthodoxy, the national religion, and replaced old customs with socialist rites. The trauma of an oppressive and anti-Russian system gave birth to various reactions and the kind of nationalism that looked back to the Black Hundred was one of many.

Pamyat was by no means the only doctrine of its kind. The organisation should be categorised somewhere between 'soft' intellectuals and various groups of radicals. Personalities such as the Noble Prize winner in Literature Aleksandr Isaevich Solzhenitsyn (1918-2008) or Igor Rostislavovich Shafarevich (1923-2017), a top-class mathematician, represented the trend of 'Memory', both in the last decades of communism in Russia and after 1990. Solzhenitsyn, in some of his essays, especially in Rebuilding Russia (Как нам обустроить Россию), ${ }^{12}$ Russia under Avalanche (Россия в обвале) ${ }^{13}$ and Two Hundred Years Together (Двести лет вместе), ${ }^{14}$ expressed his desire to reconstruct the spirit of the Russian nation and to rebuild a genuinely Russian state. After his categorical rejection of Marxist ideology, which was expressed in the famous Letter to the leaders of the Soviet Union (Письмо вождям Советского Союза), ${ }^{15}$ Solzhenitsyn propagated, above all, a return to the roots of Russianness, with its traditional folk culture and attachment to Orthodox Christianity. He did not fuel great power ambitions, as he believed that the Russians should strive for self-restraint, admit their sins, and build Russia only within its ethnic borders. ${ }^{16}$ He suggested, however, that the Ukrainians and Belarusians were an inseparable part of the Russian ethnic element. When the walls of discord arose between Russia and Ukraine in 2004, he said in an interview that leaving 25 million ethnic Russians outside the state was openly unjust. In his opinion, with regard to modern Ukraine, a significant part of the country's territory (mainly the so-called Novorossiya New Russia - or Crimea) had never constituted part of Ukraine as such before the advent of communism. ${ }^{17}$ In Solzhenitsyn's writings, the Soviet state, contrary to some Western accusations, did not promote Russification in the ethnically non-Russian provinces. Rather, it systematically destroyed 
the Russian national element and its culture with the rural substrate as the main component.

In general, as Solzhenitsyn believed, the West had made a faulty assessment of the situation in the communist East. This was not, however, a result of an erratic methodology but of a spoiling historical experience. In his famous Harvard address the writer said that

a short a time ago, relatively, the small, new European world was easily seizing colonies everywhere, not only without anticipating any real resistance, but also usually despising any possible values in the conquered people's approach to life. On the face of it, it was an overwhelming success. There were no geographic frontiers to it. Western society expanded in a triumph of human independence and power. And all of a sudden in the 20 th century came the discovery of its fragility and friability. ${ }^{18}$

Solzhenitsyn accused Western societies, especially the ruling elites, of cowardice. Having been granted well-being to an extent their fathers and grandfathers could not have even dreamed about, the people of the West were not ready to risk their precious lives when another nation's security was under threat. Western societies are obsessed with law, which leads them to manipulate it and abandon any moral imperatives that go beyond the letter of the law: 'Nobody will mention that one could still not be entirely right, and urge self-restraint, a willingness to renounce such legal rights, sacrifice and selfless risk' ${ }^{19}$

In his writings, Solzhenitsyn also makes his reader aware of the Jewish question in Russia. However, in his famous essay about this issue, he did not criticise Jewish circles in general. In contrast, he claimed that both imperial Russia and the Soviet Union did not offer proper conditions for making Russian Jews equal citizens. In this way, he explained the overrepresentation of Jews in Bolshevik organs of power. ${ }^{20}$

Igor Shafarevich perceived this problem in a slightly sharper way. In his frequently criticised book The Three Thousand Years' Riddle (Трехтысячелетняя загадка) ${ }^{21}$ and several other texts, such as the famous Russophobia (Русофобия), ${ }^{22}$ he suggested that it is unfair to state that the Russian Revolution and communism were originally created by Jews. However, because of their insularity and traditional messianism (a belief which was later deprived of its religious sense), they were naturally inclined to approve of the Marxist ideology as a transformed instruction on how to save the world. In other words, the Jews were not the ones who initiated revolutionary socialism in Russia, but the ultimate triumph of the revolution would not have been possible without the zeal presented by revolutionaries of Jewish descent. ${ }^{23}$ Shafarevich's main preoccupation, however, was not the Jewish question but rather the problem of Russia's internal enemies. His Russophobia is a study of various forms of dislikes toward his country (although he is aware that this kind of resentment is by no means reserved for Russia). As he claimed, 
there are several thinkers and activists living inside Russia or the West who have discredited the Russian past, its destiny, traditional religiosity and its imaginary 'slavish soul', and who, last but not least, reject Russia's positive contribution to the world's history. ${ }^{24}$ Shafarevich's considerations provide additional evidence for the argument that the Russian nationalism of recent decades is rather reactive. It began as a criticism of the destructive power of communism and continued as a criticism against Russophobia.

The presence of Russophobia in Europe (and the West in general) is perhaps at a similar level as it is amongst internal dissidents, yet how to explain its enduring popularity, a factor which became even more obvious after the Cold War? Shafarevich provides a more analytical and historical critique of the West than Solzhenitsyn. The mathematician explains its mobilisation with Pico della Mirandola's diagnosis (given in his De hominis dignitate), according to which the new man will gain power over things and people, being able to communicate with all levels of the universe. In general, the will and power over nature and man became the imperative of homo occidentalis. This was the driving force behind Francis Bacon's experimental method and desire to uncover the secrets of nature, which prompted Newton's discoveries and the achievements of the London Royal Society. In terms of social instincts, the West was driven by the same trigger as the Roman Empire: the Augustinian libido dominandi. This feature became a sufficient condition and breeding ground for the Roman desire for profit. It is the same spirit that permeates Schopenhauer and Nietzsche's philosophies; and the modus vivendi undisguised by Marx was, after all, the struggle for an ultimate solution. ${ }^{25}$

Shafarevich sees the most fundamental properties of European civilisation in the social consequences of capitalism, which itself is responsible for social atomisation. Social changes in the West were subordinated to the needs of capitalism. In practice, this led to the concentration of the population in cities and industrial centres and the loss of human resources in rural areas. It was actually a violation of the natural distribution of the population in their countries, but also an axiological transformation. The power of Ancient Greece, even the metropolitan city of Athens, was created primarily by the culture and political organisation of farmers coming to the cities. For centuries, the main pillar of European societies was the peasantry until that disastrous breakthrough, which meant the expulsion of people from their natural environment and exposing them to the temptations of the city. The change was particularly dramatic in England, where peasants were violently forced to leave the countryside and create an urban proletariat. In subsequent centuries, the tissue of the agricultural and artisanal life of the colonial countries was annihilated, generating millions of victims of the system. The silent majority was subordinated to the power of the city and industrial regions. ${ }^{26}$

It is Russia that became a special experiment in this process. It was a country where, on the eve of the revolution, peasants made up four-fifths of the population. The peasantry remained in a state of constant dissatisfaction over low incomes. The February Revolution of 1917 brought the 
Constitutional Democrats and Socialist Revolutionaries to power, i.e. parties seeking to solve this problem by dividing up the land owned by the aristocracy and plantation owners. After the October Revolution, the Bolsheviks tried to implement this postulate through the Land Decree, but all the data indicate that the expansion of farms was symbolic. The following activities were in fact directed towards the 'liberation of peasants from the rural idiocy'. ${ }^{27}$

These premises led the mathematician to the conclusion that there were deep parallels between the civilisation of the liberal West and the Stalinist version of communism. Both are based on the ideology of progress understood in materialistic terms. Both chose the technocratic model of development. Both the West and Sovietism became urban civilisations, rejecting with contempt not agriculture per se, but rather the peasant mentality. Both are therefore based on dangerous utopias that lead to dehumanisation and, consequently, to self-destruction. In both cases we can observe a rejection of the Aristotelian principle of the limitations of all organic bodies. In classical metaphysics, organicity logically entails limitation, while the principle of technical civilisation is development without limits in any aspect. In other words, capitalism, which is a creation of the European West, and technocratic Communism are in fact two roads to the same precipice. ${ }^{28}$

\section{The trauma of the fallen empire and 'imperial nationalists'}

The internal crisis and final collapse of the USSR led to two different reactions: some felt empowered to speak on behalf of the Orthodox nation, oppressed by the reds, but there were also those for whom the fall of the empire was the greatest problem. This kind of discomfort resulted both from the injury which was inflicted on megalomania, as well as from the awareness that many ethnic Russians, who belonged to a once- dominant imperial nation, found themselves outside the borders of the modern Russian state. What seems quite curious is that a non-communist (but statist) party appeared two years before the end of the USSR: the Liberal-Democratic Party of the Soviet Union (Либерально-демократическая партия Советского Союза, ЛДПСС), which was officially registered on 12 April 1991. Although it was established by Vladimir Bogachev, very soon another active politician Vladimir Volfovch Zhirinovsky (Eidelstein) - took the chairman's position for more than three decades. This happened even though Bogachev, whose ideological roots were in the Democratic Union, tried to remove Zhirinovsky from the party in 1990 because of his real or alleged cooperation with the KGB.

After the collapse of the USSR, the party changed its name to the LiberalDemocratic Party of Russia (Либерално-Демократическая Партия России, LDPR) and assumed a controversial ideological shape. On the one hand, it is liberal and supports the free-market and freedom of speech. It is absolutely democratic and is in favour of the people expressing their power in free elections. The LDPR rejects communism and Marxism and supports the idea of the rule of law. The problem lies in the fact that Zhirinovsky and his 
people were unnaturally nation-oriented and never accepted the collapse (or partitioning) of the state. They proclaimed the need to reconstruct the empire while avoiding its previous red coating. In their minds, the Russian Empire (as well as the Soviet Union) did not act for the sake of the Russian nation. As their programme manifesto states, the Russians never had their own territory in Russia, as was the case with the minorities. That is why it is now impossible to allow the right to national self-determination within the limits of Russia or any other official language than Russian. Zhirinovsky would like to limit the West's influence and genuinely promote Russian culture. What seems more dangerous is his belief that the Russians were the most divided people after 1991. To reunite them, it is necessary to peacefully return the territories which were lost due to the Belovezha Accords in 1991. ${ }^{29}$ The LDPR is supposed to be a 'licensed opposition', as it held the position of the third power in the State Duma, the lower house of Russia's National Assembly, for many decades.

Zhirinovsky's view of Europe is generally negative. Neither in the party's programme nor in less official publications is any possible friendly relationship mentioned. On the contrary, the necessity of separation is instead emphasised. Russia should pursue the route of autarchy rather than imitate anyone else, especially Western civilisation. After all, what are the so-called Western values? They are mainly individualism, selfishness, a sense of superiority, a hard, inhuman struggle based on social Darwinism, contempt for weakness and poverty, colonial expansionism and plunder. It is the Weberian Protestant ethic that ultimately formed animalist capitalism and theoretically justified racism, Nazism and fascism. This 'cultural code of the West' must certainly not be instilled in the youth. Ukraine is testimony to this experiment, where its deplorable results are all too visible. ${ }^{30}$

Similar but less aggressive strains are characteristic of the Congress of Russian Communities (Конгресс русских общин), which existed between 1993 and 2003 before being refounded in 2011, as well as the Rodina (Homeland) Party, both of which were launched by Dmitry Rogozin. However, some other moderate nationalists, such as Sergey Glazyev or Sergey Baburin, played a considerable role in the actions of the Congress and Rodina, which after its creation in 2003 ceased to exist in 2006 but was later reborn in 2012. The Congress is an organisation that unites Russian minorities predominantly in the former Soviet republics, whereas Rodina is considered to be an internal actor. At the beginning of the 2020s, neither the Congress nor Rodina could be regarded as the leading nationalist forces in Russia.

The attitude of Dmitry Rogozin himself and the environment of the Congress of Russian Communities-Rodina towards Europe seems much less critical than it is in the case of the LDPR. Understandably, activists from this circle resent the apparent fact that new EU states do not respect the rights of the Russian minority. Generally, however, and perhaps surprisingly, Europe is understood by Rogozin as a common home, and also for Russians. Europe is a temple built from the sacred stones of the past, yet one which contemporary Western civilisation is abandoning. Rogozin is critical of European tolerance, 
which takes the form of cold isolation, behind which hides increasing xenophobia. Europeans pretend that nothing bad is happening in regions they consider 'foreign' because it is convenient for them. In reality, however, a pronounced shift to the radical right can be expected in Europe, largely triggered by the sense of being threatened by immigration. Against the background of what is likely to come, Russian nationalist groups will prove to be innocent lambs. Rogozin himself, whose rhetoric has weakened significantly after years as the ambassador of the Russian Federation to NATO, considers himself a right-wing politician, but a 'Russian Gaullist' rather than a National Front xenophobe. ${ }^{31}$

A similar (i.e. not very impressive) degree of popularity is characteristic of another imperialist nationalist party, Great Russia (Великая Россия). Тhe official founder of the party was Dmitry Rogozin, but the actual leader of this formation was Andrei Savelyev, who was the author of many high-profile publications. The party's programme envisages Russia only for real Russians, i.e. those people who were brought up in the circle of Russian culture and professing Russian values. At the same time, Great Russia propagates the idea of a unitary state that does not allow any foreign element to influence it. ${ }^{32}$ Great Russia is one of the groups that consider a specific conservativenational text - the Russian Doctrine - to be an important part of their view of Russia and the world. It was created in 2005 by a broad group, with Andrei Kobiakov, Vitaly Averyanov and Vladimir Kucherenko as the most active experts. The authors do not treat the document as a party programme but rather a set of guidelines and beliefs that can be used by various groups and institutions. The starting point of the document is the remark that today's Russia is in deep crisis and the scenarios of a total collapse or stagnation are by all means possible. One of the basic positive postulates of the initiative is to develop a national idea based on tradition. It is therefore a typical example of conservative nationalism. As the authors believe, the ideas of 'nationalism' and a 'national state' in recent centuries have often worked as subversive slogans, and still function in this capacity (such as the so-called colour revolutions). Nationalism is considered to be an occasion for the isolation and decomposition of the existing state orders and old civilisations. For historical Russia, such nationalism is not characteristic. Russian nationalism is supposed to be of a completely different type: it is not the 'nation' in itself which is valuable, but the national tradition in it; the nation, although changing and developing in time, does not change itself. In the history of Russia, the nation state does not appear as a den for a separate tribe, but rather as an orphanage, which adopts tribes who then become part of the great Russian nation. ${ }^{33}$ This approach is one of many examples where Russia is treated not as an ethnic phenomenon, but rather as a separate civilisation.

The founders of the Russian Doctrine regard the European influence in Russia as quite problematic, tending to resort to Koliev, who in his book Nation and State claims that there are two approaches that assess the relationship between the nation and the state in different ways. For Western scholars, 
a nation is historical and to a large extent constructed by the authorities, while for Eastern ones, artificiality may refer to a state which may turn out to be chimeric and anti-national. The use of Western approaches and an attempt to forget the prehistory of state formation have a harmful effect on the spiritual health of Eastern European nations. They are beginning to be credited with the model of a Western-style state, which is one of division and assimilation. The peoples characterised by various social and sub-cultural layers find themselves in conditions which supposedly split them up into small units in order to form national states of the Western type. Meanwhile, this process can only be stopped by the national core, which has gathered other peoples around itself and formed a national hierarchy within an empire.

Compared to European modernity, postmodernists have advanced even further in the decomposition of the idea of an 'organic nation', they generally consider the nation a 'cultural fiction' or an 'ideological mirage'. The roots of this understanding lie in a deliberate narrowing of perspective: if we propose that we consider a person as a unity of heredity, upbringing and situation, then modernists, willingly or not, ignore heredity, and postmodernists narrow the perception of social phenomena to 'situation', 'socialisation', rejecting not only the 'genetic' element of personality, but also their upbringing. Postmodernists, therefore, reproduce the scheme of an atomised society of scattered individuals alienated from each other, who appear from nowhere as adults and complete 'persons' in themselves. ${ }^{34}$

There is an obvious controversy as to whether another fundamental phenomenon in Russia's political and intellectual life - the neo-Eurasianist movement headed by Aleksandr Dugin and represented previously by such thinkers as Aleksandr Panarin and Geydar Dzhemal and now by Valery Korovin - can be considered a specific case of nationalism. The Eurasianists reject the ideological and geopolitical dominance of the Western, 'Mondialist' and 'Talassocratic' proposal with its democracy, free-market, and the apology of liberalism which is focused on the individual. What they propose instead is the ideological power of the traditionalistic Eurasian continent, which is a defender of religion, communitarianism and faithfulness to traditional commitments. ${ }^{35}$ This radical anti-Western, anti-liberal, and anti-democratic doctrine could be perceived as a kind of nationalism only if one accepts the existence of an imaginary 'Eurasian nation'. Otherwise, it should rather be treated as a specific example of quasi-conservative totalitarianism.

The Eurasian option can be treated as predominant in the initiative of the Izborsky Club, which is an association of nationalistic, conservative, antiliberal and anti-American thinkers and activists that was founded in 2012. The chairman of the club, Aleksandr A. Prokhanov, is a well-known writer who represents the most characteristic and a quite paradoxical ideological trait of the group: the tendency to reconcile two incompatible traditions - the traditionalism of Orthodox, monarchist 'white' Russia and the heroism of the Soviet (mainly Stalinist) period which was reflected in the victory over Nazism. The leaders of the club describe their orientation as 'patriotic' and would like 
to contribute to the formation of a new agenda in the Russian media - the conquest of information niches which objectively arise in connection with the 'ideological and moral decline' of the liberal community. ${ }^{36}$

The Izborsky Club issues its monthly journal Izborskiy Klub (Russkie strategii) with surprising regularity, consistently maintaining its aggressive anti-Western tone on the one hand and a dreamer's approach toward imaginary prospects on the other, which is also reflected in Prokhanov's 2019 book In Search of the Russian Dream (B поисках русской мечтыл). ${ }^{37}$ Laruelle claims that today's studies on Russian nationalism concentrate more on classifications but 'ignore the issue of institutional location'. Continuing this position, she finally concludes that the patronage of the Kremlin over the club seems unlikely and that support for the group should rather be traced to influential rightist politicians, such as Rogozin and Sergey Glazyev. Moreover, according to her, allies should be sought within the military and militaryindustrial complex and the anti-liberal camp, which tries to influence the main centre of power. ${ }^{38}$ This remark seems reasonable, as a similar case of support from the military circles characterised the publication initiatives of Dugin and the early neo-Eurasianism of the 1990s. In other words, the 'relative' impact of the imperialist, 'geopolitical' nationalists ought to be perceived from the perspective of various influences surrounding the Kremlin, with a particular emphasis on the role of the 'force camp' and media radicals in the style of Mikhail Leontyev, who oppose the supporters of free-market commitments and cooperation with the West.

The essence of the neo-Eurasianist anti-Westernism lies in the belief in the so-called mondialism, the Atlantic, predominantly Anglo-Saxon, doctrine, which is supposed to subordinate the rest of the world to the philosophy of extreme individualism, where any obligations to one's community are dissolved in the waters of the geopolitical sea. However, for Dugin, Europe is not doomed to sink beneath the waves of Atlanticism: there is still another option - the 'continental' German-oriented vision of a unity faithful to its traditional communitarian authoritarianism. Central Europe, contrary to Mackinder's expectations, should follow the vision of Naumann's Mitteleuropa, which found its best implication in the works of Karl Haushofer. What Dugin himself proposes is a European Empire, predominantly led by the German nation, a reliable partner of Eurasia, yet dominated by Russia. ${ }^{39}$

\section{The radical anti-communist response}

16 October 1990 is the birthdate of Russian National Unity (Русское национальное единство), a nationalist organisation which grew out of Pamyat and was established by Aleksandr Barkashov, its former member and Vasilyev's bodyguard. In his major programme manifesto, which was formulated in 1994 and entitled The ABC's of a Russian Nationalist, the author tried (from a nationalist point of view) to comprehend the current crisis in Russia and to outline possible ways to overcome it. He strongly contrasted the 
concepts of patriotism and nationalism. A patriot is a statesman, and the state has been working against the Russian nation (including not only the Great Russians but also the Ukrainians and Belarusians) since 1917. Therefore, the $A B C$ 's suggested breaking this anti-national state by a national social revolution, which was supposed to establish a 'national dictatorship'. The author does not hide his positive attitude toward Nazism. On the other hand, Barkashov associated the Bolshevik Revolution with the conspiracy of a transnational financial oligarchy, i.e. a controlling stake which belongs to Jewish financiers. The emissary of this specific red oligarchy in Russia was Leon Trotsky. Nevertheless, the USSR as a whole was not so unambiguously evaluated. By 1937, among the Bolsheviks of Slavic origin, a faction of 'National Communists' was formed, which then engaged in an internal party struggle with the Jewish 'internationalists'. However, in 1985, the latter evolved into 'democrats' whose invention of 'perestroika' led to the transformation of Russia into a 'semi-colonial third world country'. Therefore, the Russian nation is obliged to resist this influence, and the first stage of resistance is the transformation of a collection of people into a nation through the growth of national self-consciousness. The second is the creation of a unitary national state that is headed by an omnipotent National Council. ${ }^{40}$

In September 2000, the organisation split into factions after the secession of a group led by Oleg Kassin and Yuri Vasin. In subsequent years, further disintegration ensued but it must be remembered that, at least until 1995, Russian National Unity (RNU) nearly monopolised the radically nationalistic camp by developing 58 regional branches inside the Russian Federation and four branches abroad. These were located in Belarus, Ukraine, Latvia and Estonia. $^{41}$

RNU and its daughter organisations, such as Russian Revival (Russkoe vozrozhdenie), are only the most radical incarnations of the same stripe as Pamyat or the considerations of conservative-nationalistic intellectual prophets. They all reacted to the destruction of the Russian nation, which they felt had been caused by communism and the first years of the Russian Federation. Their leaders did not see Russians as being responsible for the revolution and the socio-economic catastrophe of the 1990s. Instead, they perceived the source of evil as existing in an alleged Jewish or Masonic conspiracy. Only in this sense did their ideology approach Nazism and finally succumb to the temptation of extreme racist anti-Semitism. However, just as with the origins of the Nazis, RNU's racism was only a rather late and random form of the pseudoscientific exploration of the political, social and economic disaster in the 21 st century. As Dunlop correctly stated, the strength of the RNU's neo-Nazi movement 'lies in the self-imposed weakness of the Russian state'. ${ }^{42}$

Particularly noteworthy is the fact that RNU, which is very critical of the contemporary Russian political elite and does not perceive the Russian Federation as a state that could satisfy the nation's interests, is also very reluctant to express any comments on Europe or the West in general. Contrary 
to the imperial nationalists or totalitarian neo-Eurasianists, the Russian National Unity sees the enemy not in the West but in the multinational corporate state, one which preys on the flesh of the Russian people, torn apart by a supranational parasitic oligarchy and foreign elements in the country.

However, if this is the case, we can realise that the Russian nationalism of the post-Soviet era reacted to at least two different phenomena: the social disaster of the nation and the 'inadequacy' of the state. As it is, the social collapse might have been caused by the inadequacy of the new Russian state: both aspects overlapped.

\section{The national socialists - a response to the pressure of 'racial strangers'}

Another option for ethnic nationalism in Russia is the national-socialist trend which was represented predominantly by the Slavic Union (Славянский Союз, Slavyansky Soyuz, SS), and which was established in September 1999 by Dmitry Demushkin, a legendary national-socialist leader. The Union's association with Nazism was quite obvious, especially if one considers the abbreviation (SS) which stands for the name of the organisation. Its ideology embraced such postulates as the creation of a superman, racial purity and the predominance of ethnic Russians in the state (without the extermination or displacement of other ethnic groups). Russia is generally treated as the victim of a foreign occupation..$^{43}$

After the Slavic Union was banned (27 April 2010), Demushkin and his companions created another organisation with the same Russian acronym (SS): The Slavic Power (Славянская Сила), and after the subsequent ban, his third national-socialist association - The Russians (Русские), which was also outlawed as extremist in 2015. It proclaimed its mission to be one of upholding the rights and interests of the Russian population, both within the country and abroad. The association advocated the creation of a Russian national state and government.

Demushkin, as a devout nationalist, however, is paradoxically far from European nationalists but not because of their axiological profile. He points to a ridiculous trait of the European far-right: their cooperation with the Russian authorities. In other words, the ideological line of the Slavic Union/ The Slavic Power/The Russians is relatively close to the RNU, and therefore extremely critical of the Kremlin, which is accused of neglecting the interests of the Russian nation and subordinating it to a multiracial Eurasian blend. That is why such European creations as National Rally or the Italian Lega are criticised in ethnic nationalist circles in Russia. ${ }^{44}$

The national-socialist line was continued by various organisations, some of which were definitely extremist, even resorting to radical Western symbols and names: the National Socialist Society (Национал-социалистическое общество), Schulz-88 (Шульц-88), the Skinhead group Lincoln-88 (Линкольн88 ), etc. Many of their members were involved in several legal procedures 
which led to their imprisonment. An interesting case of a racist Nazi organisation is the National People's Party (Народная национальная партия) which was headed by Aleksandr Ivanov-Sukharevsky, who proclaimed the ideology of 'Russism', wherein the fate of the white race, especially in Russia, is illustrated as a history of a genocide, which justifies the anti-Semitic tendencies among all Russians. ${ }^{45}$ In this way the Russian ethnic and racist radicals are becoming closer to Western Nazi or fascist ideology, one additionally strengthened by the use of analogical iconography.

\section{Pro-Western and democratic nationalists}

For many years, the National People's Party was inspired by the interesting personality of Aleksey Shiropaev, the author of a scandalous but very interesting book, The Prison of the Nation (Тюрьма народа). The author intentionally paraphrased the popular term 'the prison of nations' referring to tsarist Russia as a state oppressing many ethnic groups. This time, however, we receive a story about the Russian state as an entity directed against its own nation, thus making it the object of extermination. This tendency manifested itself in the medieval inclinations of some princes to accept foreign, nonAryan influences: Byzantine Christianity (which was derived from the religion of Jews), the habits of the nomadic Turkic peoples, and Mongolian despotism, which would later master the entire philosophy of the Russian state. As Shiropaev claims, the highly genocidal Bolshevism, created by the Jewish minority, as well as the contemporary Caucasian and Asian influences, are also highly destructive. ${ }^{46}$

Later, Shiropaev, with some other activists, created the NationalDemocratic Alliance (Национал-Демократический Альянс, NDA), which has nothing in common with any of the older traditions of Russian nationalism. The NDA does not continue the traditions of the Slavophils, Pochvenniks, Pan-Slavists or the Black Hundred organisations. It rejects the Soviet legacy and radically condemns all forms of Eurasianism. It offers a kind of 'tribal' nationalism, but the outcome of the NDA's position does not resemble any of the old ethnic doctrines. The Russian nationalist tradition most commonly opposed Russia and the Russian people to the West, who were normally associated with the greatest threats. The NDA, however, contrary to Russian nationalistic statists and Orthodox traditionalists, opts for the federalisation of the state, anti-communism, the rejection of the glorification of the Soviet victory over fascism, anti-clericalism, limiting immigration from the East and the South, establishing cooperation with NATO and the European Union, and, most importantly, it advocates for a real democratisation of the state, which would allow a free expression for the Russian people about how their social life and state policy should work. ${ }^{47}$

Russian National Democrats openly declare their devotion to European values. As Nikolai Markin, one of their activists, declared in 2016, 'a normal Russian nationalist is a European'. He also believes that sentiments among 
Russian nationalists are gradually shifting from imperialism towards the ethnic, pro-European sort of doctrine. What is necessary is a 'restart' of relations with Europe and the United States. To do this Russia needs to introduce a visa regime with Central Asia, and strengthen its existing policies towards China and North Korea. Russia has the most extensive border with the PRC, which in Markin's opinion is dangerous in all respects. Being unable to choose its neighbours, Russia should establish military and political cooperation with NATO member states to prevent Chinese expansion into the Russian Federation. ${ }^{48}$

Markin's optimism, however, has not been reflected in public opinion polls in Russia. According to the data review provided by the Yuri Levada Analytical Centre on 23 Mar 2021, the intensity of European identity among Russians has been significantly decreasing since 2008. Asked whether they considered Russia a European country, 52\% of respondents said 'yes' in Sep 2008, 37\% in Aug 2019 and only 29\% in 2021. The question 'Do you consider yourself a European' received a positive answer in 35\% of responses in Aug 2008, 33\% in Aug 2019 and 27\% in Feb 2021. The general tendency revealed by Levada's research is that the younger the generation, the less it considers itself to be European. ${ }^{49}$

\section{The 'cultural' nationalists}

Another trend of Russian nationalism adheres to a cultural definition of the doctrine. The early 1990s gave birth to a radical change in Russian policies, which manifested itself in such phenomena as wild capitalism, 'unfair' privatisation, oligarchism perceived as 'corrupted statism', lenience toward the Islamic element in the Northern Caucasus, and Russia's uncontrolled access to the rules of globalisation. None of these points were in any way familiar to Russian cultural heritage. This caused a reaction in the shape of the Russian Nationwide Union (Русский общенациональный союз, RONS), which later appeared in the media as Russia Will Be Freed Вy Our Forces (Россия Освободится Нашими Силами) with Igor V. Artemov at the helm. As they declared in their creed, the organisation does not accept the current political regime in the Russian Federation, as under it Russianness is being gradually destroyed and Orthodoxy is being perverted. What they propose instead is a nation-focused state based on Christian values, national control over natural resources, genuine democracy that should replace the corrupted regime which is supported by socially uncontrolled oppressive state formations, and, last but not least, a strict limit on immigration. ${ }^{50}$ In other words, RONS is trying to avoid criticism of Europe or the West in general, despite using some Slavophile patterns. The founders of the movement created its programme as the manifesto of a traditional Christian Democratic party.

This ideological line was supported by intellectual moderate nationalists of a new wave, whose explication can be found in the journal Voprosy nacionalizma (Вопросы национализма), which was for many years associated 
with its leading columnist, Konstantin Krylov, the founder of the unregistered National-Democratic Party (Национально-Демократическая партия), and was later directed by his widow, Nadezhda V. Shalimova.

\section{The religious challenge}

One of the most important aspects of Russia's social collapse was the radical eradication of religious life in the state. In the last years of the Russian Empire, Russia was (by all means) a religious country. Its multi-ethnic population practised their religions regularly in a very traditional, rather than modernist, way. The Orthodox Church, which was the state religion, enjoyed the position of real power. It had at least 87 million adherents, most of whom attended liturgical services weekly on Sundays, as well as on other red-letter days. However, the real situation was much worse than the official narrative of the throne and the clergy. In the 19th century, the process of gradual secularisation in nearly all social strata of the Empire progressed, and after 1900 even the highest hierarchs admitted that they were experiencing the beginning of the end. ${ }^{51}$ However, after the collapse of communism, the image of a lost religious paradise was idyllic and a tendency among nationalists to create a new form of the Orthodox state became noticeable.

This is the background of the phenomenon of Russian Orthodox nationalism as represented by such organisations as the Union of Orthodox Banner Bearers (Союз православных хоругвеносцев), which was formed in 1992 and is headed by Leonid Donatovich Simonovich-Nikshich. The organisation's main propaganda slogan was imported from the 19th century with Count Sergei Uvarov's educational doctrine of 'Orthodoxy, Autocracy, Nationhood' (Православіе Самодержавіе Народность). ${ }^{52}$ The major objectives of the Union are strengthening the Orthodox faith and the establishment of an absolute monarchy with solid ties between the throne and altar. As the visionaries of an Orthodox and ethnically Russian state, the Union's leaders disapprove of the Jewish influence, as well as of mass migration from the predominantly Muslim Northern Caucasus and Central Asia into the Russian interior. A similar but less radical position is held by the Union of Orthodox Citizens (Союз православных граждан) which was established in 1995 with the intention of protecting the interests of the Russian Orthodox Church and introducing the spiritual principles of Orthodoxy into all spheres of life. The organisation not only functions in Russia but also in Ukraine and Kazakhstan.

The zeal of both unions may seem unnecessary in a country where the number of Orthodox temples, monasteries and believers shows an upward trend. However, the reality, as it used to be in the imperial era, is far from clear. One could suppose that, after the collapse of the atheistic and destructive communist regime, a religious upper tide would flood Russian soil. In fact, according to the Pew Research Center, Russia in 2017 was $71 \%$ inhabited by Orthodox Christians, but only $6 \%$ of them attended 
church weekly. This is a modest percentage if one considers the fact that in Ukraine and Belarus the index reaches $12 \%$, and in the case of the Ukrainian Byzantine Catholics and Polish Roman Catholics it exceeded $40 \% .{ }^{53}$ Only after considering these facts can we understand why Russian Orthodox nationalists find it necessary to establish an autocratic and theocratic state: from the perspective of genuinely realised values, they feel like a minority in their own country.

The attitude of the ultra-conservative Orthodox nationalists toward the West is moderately negative. The activists are not outspoken against Europe as such or any other outcome of Western civilisation. However, they loudly express disapproval of certain cultural phenomena from the West, such as gay parades, Harry Potter or Madonna's music. A portrait of the singer was even burned in public, although this was denied by the church authorities, who oppose any aggressive forms of expressing views. ${ }^{54}$

\section{The Central Asian and Caucasian challenge vs the anti-immigrant organisations}

The Orthodox unions were probably the first to realise the new threat to the image of Russia as an Orthodox Christian, East Slavic domain. In the 1990s, Russia was relatively unattractive for hypothetical newcomers. However, after the beginning of the new millennium, the economic situation improved and the metropolitan areas were flooded by 'internal' immigrants from the North Caucasus and workers from the previous Soviet republics of the South Caucasus and Central Asia. Some of the immigrants, especially the Christian Georgians and Armenians, did not cause much of a problem. However, the North Caucasian incomers were associated with crime and Islamic or irredentist terrorism. Similar fears (usually unjustified) were directed toward the Muslim economic migrants from Soviet Central Asia.

This is the background of the emergence of the Movement Against Illegal Immigration (Движение Против Нелегальной Иммиграции, DPNI), which was established in April 2002 by the two Potkin brothers, who assumed the nicknames Vladimir Basmanov (the first co-ordinator) and Aleksandr Belov, his successor between 2008 and 2010 when Vladimir Ermolaev became the chairman of the movement's National Committee. It was recognised by the Moscow City Court as extremist and banned in April 2011 but is still functioning underground. The ideology of the DPNI, supported by political actions and riots such as the anti-Caucasian pogrom in Karelian Kondopoga in August-September 2006, is radically anti-immigrant and generally aims at the eradication of any illegal influence of foreigners in the territory of Russia. Moreover, it postulates the creation of a policy that would support adequate education for Russian citizens so as to avoid the need to accept any qualified or unqualified migrant labour forces. ${ }^{55}$

The DPNI programme contains provisions analogous to those proposed by anti-immigrant groups in Europe and the United States. Among the most 
concrete, we find the postulate to prevent marriages of convenience, which facilitate access to Russia for people representing foreign values. When discussing this topic, the authors of the programme directly refer to solutions used in European countries. ${ }^{56}$

In 2011, the legacy of the DPNI was taken up by The Russians, where the previous DPNI anti-immigrant activists had to share their political convictions with the successors of the Slavic Union.

\section{Conclusions}

There is no doubt that the contemporary forms of Russian nationalism only partially resemble those of the Russian Empire era. The ideological, political, social and economic challenges of the post-Soviet times were different; this is reflected in the shapes which Russian nationalism assumed until the collapse of the USSR. In each of the studied cases, it was possible to identify new, specific challenges for the nation and state, which resulted in a specific continuation of old trends and the emergence of new ones. The final years of communism and the 1990s gave birth to a nostalgic or aggressive form of nationalism, which grew up on the soil of deprivation: the Pamyat' Front, and the sublime conservative-nationalist intellectuals wanted to recreate the previous form of Russia, which was actually a utopian idea because of the completely different historical context.

The trauma of the fallen Red Empire gave rise to the appearance of imperial nationalism. The statist nationalists aimed at the recreation of the Russian Empire with various ideological coatings. Some ideologists, for whom the state defines the nation, created a fifth column in the countries of the 'near abroad'; some, like the LDPR aimed at the reintegration of the USSR without the Marxist doctrine; instead, they proposed Russification. In some cases (such as the Eurasianists or the Izborsky Club), the main preoccupation was to work out a new state idea to combat American leadership and liberal depravity and propose a new icon, where Stalin, one of the worst persecutors of the Orthodox church, runs a choir of Soviet commanders under the patronage of the Holy Virgin.

For those who believed that the collapse of the empire was not the core, but only a consequence of the degeneration of the people, it was necessary to add the ethnic component to the doctrine to find a remedy for bad times. This was the case of RNU; but when the ethnic aspect was absolutised, such phenomena as neo-Nazi organisations were a natural consequence. The ideologies of the Slavic Union or the National People's Party, however, could not respond to the need for a civilisational identity, and thus Shiropaev's initiative to bring Russian nationalism closer to the West revealed a new, 'ethnically European' agreement platform.

Similar attempts to save Russian identity through its religious and folk traditions in the Eurasian storm characterised the 'cultural' trend of nationalistic thought. Even the extreme Orthodox fundamentalists disagreed with 
the Eurasianist temptation, preferring traditional Christian values without resorting to any alliance with the Eastern partners of the Russian nation. The anti-Eastern, especially anti-Islamic option, is the main trait of the DPNI and other smaller groups which follow the example of Le Pen's Rassemblement National and step in line with the Italian Lega, the Dutch Party for Freedom, or Pegida, which respond to the threat of replacing native social orders and values with culturally foreign, usually Islamic, elements.

The Russian nationalism of the post-Soviet times reveals a need for instrumentalist descriptions, since the manipulation of the population's fears and biases was designed to maintain a continual mobilisation and 'geopolitical vigilance. From an alternative perspective, however, the spontaneous voices which grow from the everyday experience call for a research approach that is rooted in the framework of the primordialist paradigm.

The key divergence in the developmental process of contemporary Russian nationalism shows a close correlation with the attitude of individual nationalist circles to Europe in terms of heritage and contemporary manifestations of Europeanness. The imperialist version of Russian nationalism clearly emphasises Europe's hostility towards Russian civilisation, pointing to Western expansionism, including cultural and economic developments, as phenomena resulting from a developed individualism and a spirit of violence. In the case of neo-Eurasianism, we are even dealing with a geopoliticalmystical juxtaposition of Western Atlanticism (as the den of degenerate capitalism, progressivism, abolition of obligations towards communities) and continental Eurasia, the land of tradition, communitarian sacrifice and state subsidiarity. In the 'great power' vision, Europe is seen as part of the Atlantic power, which justifies the intention to diminish Western influence and make Russia an equal partner in international relations.

'Cultural' nationalism, including religious nationalism, despite recognising obvious differences, does not perceive Europe as a significant problem. It sees the real threat rather in the internal weakening of traditional commitments. On the other hand, racist, ethno-nationalist and anti-immigrant circles resort to some European inspirations, and sometimes even refer to the symbols and nomenclature of the European radical right. The most radical pro-Westernism is characterised by the national democrats, who seem to have gained some popularity in recent years.

One has to remember that the criticism of Europe presented by imperialistic nationalists in Russia is not a straightforward but rather a reversed equivalent of the nationalistic radical movements in Western Europe. European extreme right-wingers in France, Germany, the Netherlands or Italy seem to present views that resemble Russian ethno-nationalistic ideas: the need to appreciate regional traditions or a hostility toward immigration from Muslim states. The Kremlin eagerly supports these groups (not only with friendly rhetoric, but also with financial resources). Why, then, does it act in the exact opposite manner at home, fighting its own ethnic nationalism and only leaving room to imperialists who are clearly hostile to the West? The reason seems to be the 
intention to destabilise the situation in European countries and weaken the structures of the EU. ${ }^{57}$

It is not easy to predict the future direction of Russian nationalism. The theoretically critical attitude of a significant part of the society towards a centralised and corrupt government and towards immigration from neighbouring Muslim countries may lead to the strengthening of ethnic nationalism at the expense of the imperial trend. On the other hand, however, demographic processes leading to the extinction of the Slavic and Finno-Ugric elements and to a significant increase in the share of the nations traditionally professing Islam may lead to a further weakening of the ties between Russia's population and European heritage.

\section{Notes}

1 Andrzej Walicki, The Slavophile Controversy: History of a Conservative Utopia in Nineteenth-Century Russian Thought, (University of Notre Dame Press 1989).

2 Walter Laqueur, Black Hundred: the Rise of the Extreme Right in Russia, (HarperCollins 1993). For a deeper insight into the topic of Black Hundred itself see Сергей Степанов, Черная Сотня: что они сделали для величия России, (Яузапресс 2013).

3 Frederick Charles Barghoorn, Soviet Russian Nationalism, (Oxford University Press 1956).

4 Yitzak Brudny, Reinventing Russia: Russian Nationalism and the Soviet State, (Harvard University Press, Cambridge, Mass. 2000). A new light on the 'Russian Party' in the top Communist circles of the USSR was cast thanks to A. Baygushev's book about the nationalistic inside job in the time of stagnation: Александр Байгушев, Партийная разведка, (Алгоритм 2007).

5 John B Dunlop, The Faces of Contemporary Russian Nationalism, (Princeton 2014).

6 Pal Kolstø and Helge Blakkisrud (ed), The New Russian Nationalism: Imperialism, Ethnicity and Authoritarianism 2000-15, (Edinburgh University Press 2016).

7 Marlène Laruelle, Russian Nationalism: Imaginaries, Doctrines, and Political Battlefields, (Routledge 2018).

8 Kolstø and Blakkisrud, (n 6), 22-23.

9 Лабиринт. База данных, 'Рождение общества Память', (Лабиринт, 16 February 1998), www.labyrinth.ru/content/card. asp?cardid=36234 accessed 21 June 2020.

10 Валентин Новиков, 'Публицистика: Вячеслав Овчинников: Начнем хотя бы с малых дел', http://sp.voskres.ru/publicistics/ovch.htm accessed 21 June 2020.

11 Дмитрий Васильев, 'Что-то с памятью моей стало', (Новый взгляд 15 August 1992), www.newlookmedia.ru/?p=1586 accessed 21 June 2020.

12 Александр И. Солженицын, Как нам обустроить Россию, 'Комсомольская правда', Специальный выпуск, 18 September 1990.

13 Александр И. Солженицын, Россия в обвале, (Русский путь 1998).

14 Александр И. Солженицын, Двести лет вместе (1795-1995), (Русский путь 2001).

15 Александр И. Солженицын, Письмо вождям Советского Союза, (YМСА Press 1974).

16 Александр И. Солженицын, Раскаяние и самоограничение, Из-под глыб, (YMСА Press 1974), 120-127. 
17 Александр И. Солженицын, 'Сбережение народа - высшая изо всех наших государственных задач’, (Interview), (Московские новости 28 April 2006), https:// web.archive.org/web/20120125144532/http://yavlinsky.ru/theme_of_day/index. phtml?id=2860 accessed June 262020.

18 Aleksandr I Solzhenitsyn, A World Split Apart, Address delivered on 8 June 1978, Harvard University, www.americanrhetoric.com/speeches/aleksandr solzhenitsynharvard.htm accessed 21 June 2020.

19 Ibid.

20 Александр И. Солженицын, Двести лет вместе, (Русский путь, vol. 1: 2001), $507 \mathrm{nn}$.

21 Игорь Р. Шафаревич, Трехтысячелетняя загадка, (Эксмо, Алгоритм 2005).

22 Игорь Р. Шафаревич, Русофобия, (Российское Национальное Объединение 1989).

23 Игорь Р. Шафаревич, Трехтысячелетняя загадка, (Эксмо, Алгоритм 2005), 412-413.

24 Игорь Р. Шафаревич, Русофобия, (Вече 1988), 22-29.

25 Игорь Р. Шафаревич, Зачем России Запад?, (Эксмо, Алгоритм 2005), 23-24, 57.

26 Ibid., 60, ff.

27 Ibid., 102.

28 Игорь Р. Шафаревич, 'Две дороги - к одному обрыву', http://shafarevich.voskres. ru/a28.htm accessed 27 June 2021. First published in Новый мир, 1989, № 7.

29 ЛДПР, 'Мы за русских! 111 позиций ЛДПР', https://ldpr.ru/events/We_are_111_ positions_for_the_Russian_Liberal_Democratic_Party/

30 Владимир В. Жириновский, Россия и Европа: история непонимания, (ЛитРес 2019), 3, www.litres.ru/static/or4/view/or.html?baseurl=/download_ book $/ 48621060 / 60720610 / \&$ art $=48621060 \&$ user $=896609752 \&$ uilang $=$ ru $\&$ catalit2\&track_reading accessed 27 June 2021.

31 Дмитрий Рогозин, 'Главный принцип национальной политики - люби свое, уважай чужое', https://pozneronline.ru/2020/11/30252/ accessed 21 June 2021.

32 Великая Россия, 'Программа Партии «Великая Россия»', http://velikoross.org/ programm/ accessed 21 June 2020.

33 Русская доктрина. Сергиевский проект, 'Тезисы Русской доктрины', www. rusdoctrina.ru/page95509.html accessed 21 June 2020.

34 Андрей Н. Колев, Нация и государство, (Логос 2005), 403-404.

35 Ideas represented in many works, e.g. in Aleksandr Dugin's Foundations of Geopolitics: Александр Дугин, Основы геополитики, (Арктогея 1997).

36 Изборский клуб, 'О клубе', https://izborsk-club.ru/about accessed June 232020.

37 Александр А. Проханов, В поисках русской мечты, (Книжный мир 2019).

38 Marlène Laruelle, 'The Izborsky Club, or the New Conservative Avant-Garde in Russia', (2016), The Russian Review, 75, 626-627, 643-644.

39 Александр Дугин, Основы геополитики, (Арктогея 1997), 220 ff.

40 Александр П. Баркашов, Азбука русского националиста, (Слово-1, 1994).

41 Владимир Прибыловский, Вячеслав Лихачев, Русское Национальное Единство, (Центр «Панорама» 2000), 82, nn.

42 John B Dunlop, 'Alexander Barkashov and the Rise of National Socialism in Russia', (1996), 4, Demokratizatsiya, 4, 519-530.

43 Comp. Александр Верховский, Галина Кожевникова (Eds), Радикальный русский национализм: структуры, идеи, лица, (РОО Центр «Сова» 2009), 155-156.

44 Олег Колосов, 'Почему Демушкина послали нах европейские националисты?', LiveJournal, https://rons-inform.livejournal.com/2393203.html accessed 21 June 2021. 


\section{Joachim Diec}

45 Александр К. Иванов (Сухаревский), 'Три источника русизма', https://web. archive.org/web/20120821100103/http://nnpr.su/stat/iv/triist.htm accessed 27 June 2020.

46 Алексей А. Широпаев, Тюрьма народа: русский взгляд на Россию, (Москва 2001).

47 Национал-Демократический Альянс, 'Общая информация', https://vk.com/naz dem accessed 21 June 2020.

48 'Русский националист: Россия - это Европа' Activatica, http://activatica.org/blogs/ view/id/2827/title/russkiy-nacionalist-rossiya-jeto-evropa accessed 21 June 2021.

49 Аналитический центр Юрия Левады, Россия и Европа, www.levada.ru/2021/03/ 18/rossiya-i-evropa-2/ accessed 23 Mar 2021.

50 Россия Освободится Нашими Силами, 'О движении', http://ronsslav.com/o-nas/ accessed 21 June 2020.

51 Comp. Comp. Лариса А. Андреева, 'Феномен религиозного индифферентизма в Российской империи’, (2008), 4, Общественные науки и современность, 114-124.

52 The original pre-revolutionary spelling placed on the website is preserved: ' $\mathrm{O}$ Союзе Православных Хоругвеносцев', www.pycckie.org/info/index.shtml accessed 21 June 2020.

53 Pew Research Center, 'Religious Belief and National Belonging in Central and Eastern Europe', (10 May 2017), https://pewrsr.ch/3dqJEMU accessed 21 June 2020.

54 See: Ирина Кислина, Ксения Кириллова, 'Кто такие православные хоругвеносцы? Правмир, 11 August 2012, www.pravmir.ru/kto-takie-pravoslavnye-xorugvenoscy/ accessed 21 June 2021.

55 ДПНИ, 'Цели и задачи', https://web.archive.org/web/20060818014009/http://www. dpni.org/index.php?2 accessed 21 June 2020.

56 Программа движения против нелегальной иммигращии, http://lindex-ru.org/Lind ex5/Text/10930.htm accessed 21 June 2021.

57 The question of connections between radical right-wing movements in the West and the Kremlin's activity was aptly touched upon in Anton Shekhovtsov, Russia and the Western Far Right, (Routledge 2018). 